\title{
Characterization of Some Actinomyces-Like Isolates from Human Clinical Specimens: Reclassification of Actinomyces suis (Soltys and Spratling) as Actinobaculum suis comb. nov. and Description of Actinobaculum schaalii sp. nov.
}

\author{
PAUL A. LAWSON, ${ }^{1}$ ENEVOLD FALSEN,${ }^{2}$ EVA ÅKERVALL,${ }^{2}$ PETER VANDAMME, ${ }^{3}$ \\ AND MATTHEW D. COLLINS ${ }^{1 *}$ \\ Department of Microbiology, BBSRC Institute of Food Research, Reading Laboratory, Reading RG6 6BZ, \\ United Kingdom ${ }^{1}$; Culture Collection, Department of Clinical Bacteriology, University of Göteborg, \\ Göteborg, Sweden ${ }^{2}$; and Laboratorium voor Microbiologie Gent, Ghent, Belgium ${ }^{3}$
}

\begin{abstract}
Five strains of a hitherto unknown Actinomyces-like bacterium were isolated from human clinical sources, including blood cultures. Biochemical and chemotaxonomic characterization indicated that the strains were distinct from previously described Actinomyces and Arcanobacterium species. A comparative 16S rRNA gene sequence analysis demonstrated that the undescribed strains constitute a new subline within the ActinomycesArcanobacterium species complex. The closest known relative of the isolates was found to be Actinomyces suis, although a $16 \mathrm{~S}$ rRNA sequence divergence value of approximately $6 \%$ clearly demonstrated that the unknown bacterium represents a distinct species. Based on the results of the present and earlier phylogenetic investigations, it is proposed that Actinomyces suis should be reclassified in a new genus, the genus Actinobaculum, as Actinobaculum suis comb. nov. In addition, a new species, Actinobaculum schaalii, is proposed for the Actinomyces-like bacterium from human sources. The type strain of Actinobaculum schaalii is CCUG 27420.
\end{abstract}

The genus Actinomyces is a heterogeneous group of anaerobic and facultatively anaerobic, asporogenous, gram-positive, non-acid-fast, rod-shaped organisms which generally show various degrees of branching $(9,10)$. Nearly all of the currently recognized Actinomyces species occur as inhabitants of mucosal surfaces of humans and other homoiothermic animals. Some Actinomyces species (e.g., Actinomyces bovis and Actinomyces israelii) have long been recognized as pathogens of humans and animals $(9,10)$. Several new Actinomyces species associated with disease in humans have been described in recent years (e.g., Actinomyces bernardiae [4], Actinomyces europae [5], Actinomyces neuii [3], Actinomyces turicensis [14], and Actinomyces radingae [14]), and Actinomyces-like organisms are attracting increasing interest as opportunistic pathogens. In this article we report the phenotypic and phylogenetic characterization of five strains of a hitherto unknown Actinomyceslike bacterium from human sources. Based on the taxonomic results presented below, a new species, Actinobaculum schaalii, is described.

Five human clinical isolates (CCUG 19698, CCUG 29359B, CCUG $27420^{\mathrm{T}}$, CCUG 32296, and CCUG 36567) were referred to the Culture Collection of the University of Göteborg (CCUG), Göteborg, Sweden, for identification. Strains CCUG $27420^{\mathrm{T}}$ and CCUG 36567 were isolated from human blood, whereas CCUG 19698, CCUG 29359B, and CCUG 32296 originated from human urine. All of the strains were cultured on $5 \%$ horse blood agar (Columbia base; Difco, Detroit, Mich.) at $37^{\circ} \mathrm{C}$ in a $5 \% \mathrm{CO}_{2}$ atmosphere. The isolates were biochemically characterized by using the API ZYM (enzymatic profiling), API coryne, API rapid ID 32 STREP, and API rapid ID $32 \mathrm{~A}$ systems according to the instructions of the manufacturer (API bioMérieux, Marcy l'Etoile, France). For polyacrylamide

* Corresponding author. Mailing address: Department of Microbiology, Institute of Food Research, Earley Gate, Whiteknights Road, Reading RG6 6BZ, United Kingdom. Phone: (44) 118 9357000. Fax: (44) 118 9267917. E-mail: David.Collins@bbsrc.ac.uk. gel electrophoresis (PAGE) of whole-cell proteins and cellular fatty acid (CFA) analysis, the strains were grown on $5 \%$ horse blood agar (Columbia base) at $37^{\circ} \mathrm{C}$ in $5 \% \mathrm{CO}_{2}$. The PAGE analysis was performed as described previously (8). For densitometric analysis, normalization, and interpretation of protein patterns a Pharmacia LKB-Ultro Scan XL instrument with Gel Scan XL software (Pharmacia, Uppsala, Sweden) and the Gelcompar GCW 3.0 software package (Applied Maths, Kortrijk, Belgium) were used. CFA analyses were conducted by preparing fatty acid methyl esters and analyzing them by highresolution capillary gas chromatography with a model $5890 \mathrm{~A}$ instrument (Hewlett-Packard, Avondale, Pa.) as described previously (12). A cell wall murein analysis was carried out by using the methods of Schleifer and Kandler (11) except that thin-layer chromatography on cellulose sheets (Merck, Darmstadt, Germany) was used instead of paper chromatography. The phylogenetic analysis performed was a comparative $16 \mathrm{~S}$ rRNA gene sequence analysis. A large fragment of the $16 \mathrm{~S}$ rRNA gene (corresponding to positions 30 to 1521 of the Escherichia coli $16 \mathrm{~S}$ rRNA gene) was amplified by PCR by using conserved primers close to the $3^{\prime}$ and $5^{\prime}$ ends of the gene. The PCR products were purified by using a Prep-A-Gene kit (Bio-Rad, Hercules, Calif.) according to the manufacturer's instructions and were directly sequenced by using a Taq DyeDeoxy terminator cycle sequencing kit (Applied Biosystems, Foster City, Calif.) and an automatic DNA sequencer (model 373A; Applied Biosystems). The closest known relatives of the new isolates were determined by performing a database search with the program FASTA of the Genetics Computer Group package (1). The sequences of these organisms and those of other known related strains were retrieved from the EMBL and GenBank data libraries and were aligned with the newly determined sequences by using the program PILEUP (1). The resulting multiple-sequence alignment was corrected manually, and approximately 100 bases at the $5^{\prime}$ end of the rRNA were omitted from further analyses because of alignment ambiguities. A distance matrix was calculated by 


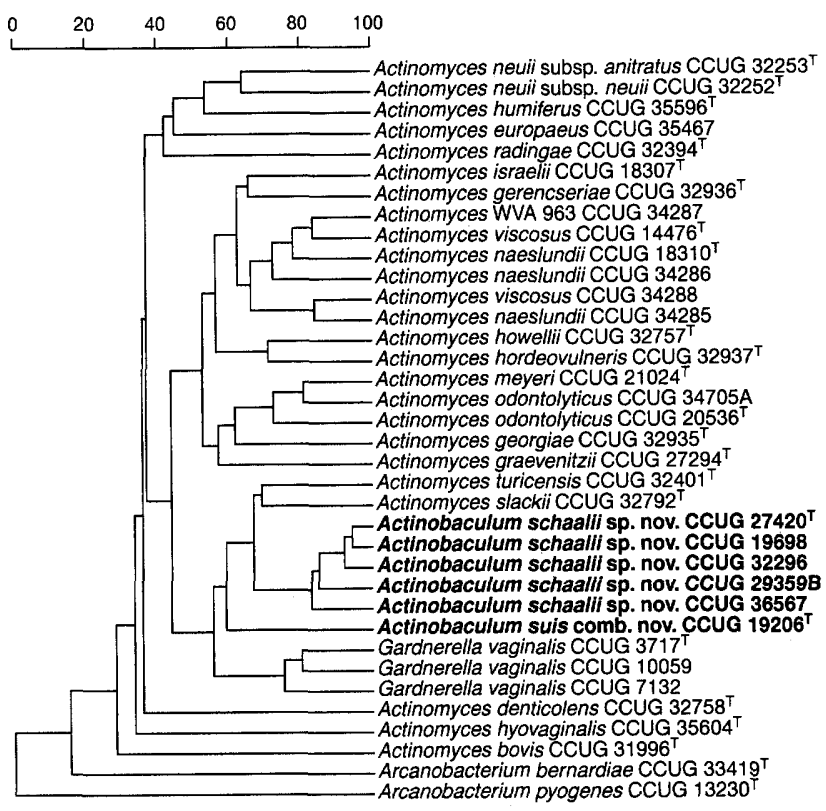

FIG. 1. Similarity dendrogram based on whole-cell protein patterns of Actinobaculum schaalii $\mathrm{sp}$. nov. and related species. Levels of correlation were expressed as percentages of similarity for convenience.

using the programs PRETTY (1) and DNADIST (using the Kimura-2 correction parameter) (2). A phylogenetic tree was constructed by the neighbor-joining method with the program NEIGHBOR (2). The stability of the groups was estimated by performing a bootstrap analysis (500 replications) with the programs DNABOOT, DNADIST, NEIGHBOR, and CONSENSE (2).

The five human clinical isolates were gram-positive, nonmotile, non-spore-forming, non-acid-fast, straight to curved rods. Some cells exhibited branching. The strains were catalase negative and facultatively anaerobic. Acetate (the major component) and small amounts of succinate were produced as end products of metabolism in PYG broth. Relatively few sugars (viz., glucose, maltose, ribose, and D-xylose) were fermented. Some of the strains fermented L-arabinose, mannose, starch, sucrose, and trehalose. All of the isolates hydrolyzed hippurate, but alkaline phosphatase, arginine dihydrolase, $\alpha$-galactosidase, $\beta$-galactosidase, $\beta$-glucuronidase, $\beta$-mannosidase, gelatinase, and urease activities were not detected. None of the strains reduced nitrate to nitrite. The analysis of the CFA contents of the strains revealed that $\mathrm{C}_{10: 0}(1.5 \pm 0.2 \%$ of the total CFA), $\mathrm{C}_{12.0}(1.8 \pm 0.3 \%), \mathrm{C}_{14.0}(7.7 \pm 1 \%), \mathrm{C}_{16: 1 \mathrm{w} 9 \mathrm{c}}$ $(1.1 \pm 0.2 \%), \mathrm{C}_{16: 1 \mathrm{w} 7 \mathrm{c}}(3.3 \pm 0.6 \%), \mathrm{C}_{16: 0}(22.9 \pm 1.6 \%)$, $\mathrm{C}_{18: 1 w 9 \mathrm{c}}(34.8 \pm 1 \%), \mathrm{C}_{18: 0}(14.4 \pm 0.9 \%)$, and $\mathrm{C}_{18: 2 \mathrm{w} 6,9 \mathrm{c}}(6.6 \pm$ $1.2 \%$ ) were the major acids. The cellular morphology, biochemical, and CFA characteristics of the unidentified clinical isolates resembled those of species of the genus Actinomyces and related taxa. The cell wall murein composition of strain CCUG $27420^{\mathrm{T}}$ was examined, and the cell wall murein type was found to be type A5 $\alpha$ (L-Lys-L-Lys-D-Glu). The same murein type is found in Actinomyces neuii and Arcanobacterium haemolyticum, and this fact reinforces the affinity of the new clinical isolates with the Actinomyces-Arcanobacterium complex of species. The whole-cell protein profiles of the five unknown strains were determined by sodium dodecyl sulfatePAGE. A dendrogram derived from a numerical analysis of the protein patterns is shown in Fig. 1. The five strains grouped

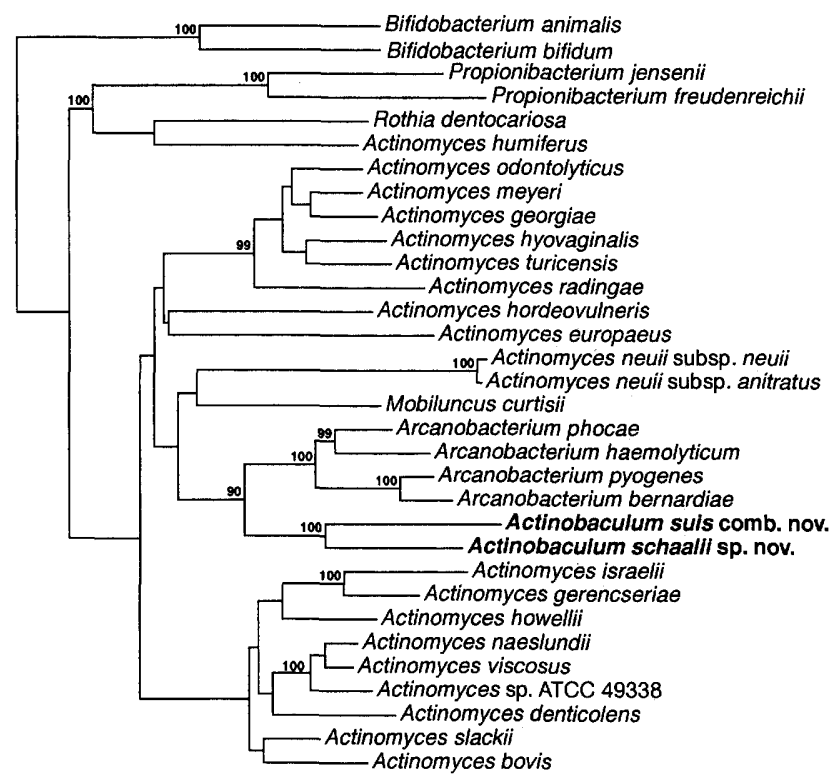

FIG. 2. Unrooted tree showing the phylogenetic relationships of Actinobaculum schaalii sp. nov., members of the genus Actinomyces, and some other taxa. The tree, which was constructed by using the neighbor-joining method, was based on a comparison of approximately 1,320 nucleotides. Bootstrap values, expressed as percentages of 500 replications, are indicated at branch points.

together and formed a distinct branch. These data demonstrate that the unknown strains represent a phenotypically relatively homogeneous group and that they are distinct from all of the Actinomyces and Arcanobacterium spp. examined. To establish the phylogenetic affinities of the clinical isolates, the 16S rRNA genes of four strains were amplified by PCR and sequenced. The sequences determined each consisted of $>1,400$ nucleotides. A comparative sequence analysis showed that the four strains were genealogically homogeneous, exhibiting 99.7 to $100 \%$ 16S rRNA similarity. Sequence searches of the EMBL and GenBank libraries revealed that the newly determined sequences were most closely related to sequences of species belonging to the genera Actinomyces and Arcanobacterium. The sequence of strain CCUG $27420^{\mathrm{T}}$ was subjected to a pairwise analysis with the sequences of Actinomyces and $A r$. canobacterium spp. and some other close relatives, and derived evolutionary distances were used to determine phylogenetic relationships. A tree depicting the phylogenetic affinities of strain CCUG $27420^{\mathrm{T}}$ is shown in Fig. 2, and the levels of sequence similarity of this strain with Actinomyces and Arcanobacterium spp. are shown in Table 1. The unidentified bacterium formed a distinct subline and displayed a relatively close affinity (approximately 94\% 16S RNA sequence similarity) with Actinomyces suis. Bootstrap resampling revealed that the association between the unknown bacterium and Actinomyces suis was statistically significant (bootstrap value, $100 \%$ ). The next closest relatives of the unknown bacterium were Arcanobacterium spp., which exhibited approximately 91 to 92\% 16S rRNA sequence similarity. Other Actinomyces spp. displayed substantially lower levels of relatedness (generally $<90 \%$ sequence similarity) (Table 1 ).

The results of both biochemical and whole-cell protein PAGE analyses showed that the five new clinical strains represent a homogeneous group of organisms and constitute a new species. Phylogenetically, the unknown bacterium forms a distinct subline within the Actinomyces-Arcanobacterium group 
TABLE 2. Characteristics that differentiate Actinobaculum schaalii from Actinomyces and Arcanobacterium species and subspecies ${ }^{a}$

\begin{tabular}{|c|c|c|c|c|c|c|c|c|c|c|}
\hline Species or subspecies & $\begin{array}{c}\text { Nitrate } \\
\text { reduction }\end{array}$ & $\begin{array}{l}\text { Urease } \\
\text { activity }\end{array}$ & $\begin{array}{l}\text { Esculin } \\
\text { hydrolysis }\end{array}$ & $\begin{array}{l}\text { Acid } \\
\text { produced } \\
\text { from } \\
\text { mannitol }\end{array}$ & $\begin{array}{l}\text { Acid } \\
\text { produced } \\
\text { from } \\
\text { xylose }\end{array}$ & $\begin{array}{l}\beta \text {-Galac- } \\
\text { tosidase }\end{array}$ & $\begin{array}{l}\alpha \text {-Glucos- } \\
\text { idase }\end{array}$ & $\begin{array}{c}N \text {-Acetyl- } \beta- \\
\text { glucosaminidase }\end{array}$ & $\begin{array}{c}\text { Beta- } \\
\text { hemolysis }\end{array}$ & Murein type \\
\hline Actinomyces bovis & $--^{b}$ & - & $\mathrm{V}$ & - & - & - & - & + & V & ND \\
\hline Actinomyces denticolens & + & ND & + & $\mathrm{V}$ & - & + & + & - & ND & ND \\
\hline Actinomyces georgiae & $\mathrm{V}$ & - & + & V & + & ND & ND & ND & - & A5 $\beta$ (L-Orn-Lys-D-Glu) \\
\hline $\begin{array}{l}\text { Actinomyces } \\
\text { gerencseriae }\end{array}$ & $\mathrm{v}$ & - & $\mathrm{V}$ & $\mathrm{V}$ & + & ND & ND & ND & - & A5 $\beta$ (L-Orn-Lys-D-Glu) \\
\hline Actinomyces israelii & $\mathrm{V}$ & - & + & $\mathrm{V}$ & + & + & + & - & - & A5 $\beta$ (L-Orn-Lys-D-Glu) \\
\hline Actinomyces meyeri & - & V & - & - & + & - & + & - & - & ND \\
\hline Actinomyces naeslundii & V & + & + & - & V & V & $\mathrm{V}$ & - & - & ND \\
\hline $\begin{array}{l}\text { Actinomyces neuii } \\
\text { subsp. neuii }\end{array}$ & + & - & - & + & + & + & + & V & - & A5 $\alpha$ (L-Lys-Lys-D-Glu) \\
\hline $\begin{array}{l}\text { Actinomyces neuii } \\
\text { subsp. anitratus }\end{array}$ & - & - & - & + & + & + & + & V & - & A5 $\alpha$ (L-Lys-Lys-D-Glu) \\
\hline $\begin{array}{l}\text { Actinomyces } \\
\text { odontolyticus }\end{array}$ & + & - & $\mathrm{V}$ & - & $\mathrm{V}$ & - & - & - & - & ND \\
\hline Actinomyces radingae & - & - & + & $\mathrm{V}$ & + & + & + & + & $-(w)$ & A5 $\alpha$ (L-Lys [L-Orn]-Lys-D-Glu) \\
\hline Actinomyces turicensis & - & - & - & $\mathrm{V}$ & + & - & + & - & $-(w)$ & A5 $\beta$ (L-Orn-L-Lys-D-Glu) \\
\hline Actinomyces viscosus & + & V & $\mathrm{V}$ & - & $\mathrm{V}$ & $\mathrm{V}$ & V & - & - & ND \\
\hline Actinobaculum schaalii & - & - & - & - & + & - & + & - & - & A5 $\alpha$ (L-Lys-Lys-D-Glu) \\
\hline Actinobaculum suis & - & + & - & - & - & + & ND & ND & - & A5 $\alpha$ (L-Lys-L-Ala-Lys-D-Glu) \\
\hline $\begin{array}{c}\text { Arcanobacterium } \\
\text { bernardiae }\end{array}$ & - & - & - & - & - & - & + & - & $\mathrm{V}$ & A5 $\alpha$ (L-Lys-L-Ala-Lys-D-Glu) \\
\hline $\begin{array}{l}\text { Arcanobacterium } \\
\text { haemolyticum }\end{array}$ & - & - & - & - & - & + & ND & + & + & A5 $\alpha$ (L-Lys-Lys-D-Glu) \\
\hline $\begin{array}{l}\text { Arcanobacterium } \\
\text { pyogenes }\end{array}$ & - & - & - & $\mathrm{V}$ & + & $V(w)$ & - & + & + & A5 $\alpha$ (L-Lys-L-Ala-Lys-D-Glu) \\
\hline $\begin{array}{l}\text { Arcanobacterium } \\
\text { phocae }\end{array}$ & - & - & - & $\mathrm{V}$ & - & $+(w)$ & $+(s)$ & - & + & ND \\
\hline
\end{tabular}

${ }^{a}$ Data from references 4 through $7,9,10,13$, and 14 .

$b_{-}$, negative; +, positive; (w), weak; (s), slow; V, variable; ND, not determined.

urease positive. Does not produce catalase, indole, acetylmethylcarbinol, hydrogen sulfide, lipase, or lecithinase; ammonia is not produced from peptone. Esculin and gelatin are not hydrolyzed. Meat and milk are not digested. Nitrates are not reduced. Major amounts of type $b$ cytochrome and minor amounts of type $c$ cytochrome are synthesized. The cell wall sugars are rhamnose and mannose. The cell wall murein type is type A5 $\alpha$ (L-Lys-L-Ala-Lys-D-Glu). The G+C content of the DNA is $55 \mathrm{~mol} \%$. Originally isolated from cases of cystitis and pyelonephritis and cases of metritis in pregnant sows. Not isolated from healthy sows but frequently recovered from urine and semen of apparently healthy boars. Sows can be infected artificially by intrarenal injection of live organisms plus $5 \%$ saponin. No demonstrable exotoxin is produced. The type strain of Actinobaculum suis is ATCC 33144 (= DSM 20639).

Description of Actinobaculum schaalii sp. nov. Actinobaculum schaalii (N. L. gen. n. schaalii, of Schaal, to honor Klaus P. Schaal, contemporary German microbiologist, for his contributions to actinomycete microbiology). Cells are straight to slightly curved rods, some of which exhibit branching. Cells are gram positive, not acid fast, and nonmotile and do not form spores. Nonhemolytic. A weak CAMP reaction occurs. Facultatively anaerobic and catalase negative. Acetate and succinate are the major end products of glucose fermentation. Acid is produced from glucose, maltose, ribose, and D-xylose. Some strains produce acid from L-arabinose, mannose, starch, sucrose, and trehalose. Acid is not produced from D-arabitol, $N$-acetyl- $\beta$-glucosamine, cyclodextrin, glycogen, lactose, mannitol, melezitose, melibiose, methyl- $\beta$-D-glucopyranoside, pullulan, raffinose, sorbitol, and D-tagatose. Hippurate is hydrolyzed. Esculin, gelatin, and urea are not hydrolyzed. $\alpha$-Glucosidase, alanine-phenylalanine-proline arylamidase, and pyroglutamic acid arylamidase are produced. Alkaline phosphatase, arginine dihydrolase, $\alpha$-galactosidase, $\beta$-galactosidase, $\beta$-glucuronidase, glycyl-tryptophan arylamidase, and $\beta$-mannosidase activities are not detected. Pyrazinamidase and pyrrolidonylarylamidase activities are shown by some strains. Nitrate is not reduced to nitrite. Acetoin is not produced. The cell wall murein type is type A5 $\alpha$ (L-Lys-Lys-D-Glu). The major cellular fatty acids are hexadecanoic, octadecanoic, and cis-delta-9-octadecenoic acids. The DNA base composition is $57 \mathrm{~mol} \% \mathrm{G}+\mathrm{C}$. Strains have been isolated from human blood and urine. The habitat is unknown but is probably the genital or urinary tract. The type strain of Actinobaculum schaalii is CCUG 27420. The source of CCUG $27420^{\mathrm{T}}$ was human blood (chronic pyelonephritis, 64year-old male). The type strain has the characteristics of the species.

Nucleotide sequence accession number. The 16S rRNA gene sequence of strain CCUG $27420^{\mathrm{T}}$ has been deposited in the GenBank database under accession number Y12329.

This work was supported in part by grants ERBCHRX-CT93-0194, B102-CT93-0119, and B102-CT94-3098 from the European Union.

E.F. is indebted to Nicklas Strömberg, Gunnar Dahlén, George Bowden, and Knut Lincoln for depositing isolates in the CCUG.

\section{REFERENCES}

1. Devereux, J., P. Haeberli, and O. Smithies. 1984. A comprehensive set of sequence analysis programs for the VAX. Nucleic Acids Res. 12:387-395.

2. Felsenstein, J. 1989. PHYLIP-phylogeny inference package (version 3.2). Cladistics 5:164-166.

3. Funke, G., S. Stubbs, A. von Graevenitz, and M. D. Collins. 1994. Assignment of human-derived CDC group 1 coryneform bacteria and CDC group 1-like coryneform bacteria to the genus Actinomyces as Actinomyces neuii 
subsp. neuii sp. nov., subsp. nov., and Actinomyces neuii subsp. anitratus subsp. nov. Int. J. Syst. Bacteriol. 44:167-171.

4. Funke, G., C. Pascual Ramos, J. F. Fernández-Garayzabal, N. Weiss, and M. D. Collins. 1995. Description of human-derived Centers for Disease Control coryneform group 2 bacteria as Actinomyces bernardiae sp. nov. Int J. Syst. Bacteriol. 45:57-60.

5. Funke, G., N. Alvarez, C. Pascual, E. Falsen, E. Åkervall, L. Sabbe, L. Schouls, N. Weiss, and M. D. Collins. 1997. Actinomyces europaeus sp. nov., isolated from human clinical specimens. Int. J. Syst. Bacteriol. 47:687-692

6. Funke, G., A. von Graevenitz, J. E. Clarridge III, and K. A. Bernard. 1997 Clinical microbiology of coryneform bacteria. Clin. Microbiol. Rev. 10:125159.

7. Pascual, C., G. Foster, and M. D. Collins. 1997. Phylogenetic analysis of the genus Actinomyces based on 16S rRNA gene sequences: description of $\mathrm{Ar}$ canobacterium phocae sp. nov., Arcanobacterium bernardiae comb. nov., and Arcanobacterium pyogenes comb. nov. Int. J. Syst. Bacteriol. 47:46-53.

8. Pot, B., P. Vandamme, and K. Kersters. 1994. Analysis of electrophoretic whole-organism protein fingerprints, p. 493-521. In M. Goodfellow and A. G. O'Donnell (ed.), Modern microbial methods. Chemical methods in prokaryotic systematics. J. Wiley and Sons, Ltd., Chichester, United Kingdom.
9. Schaal, K. P. 1986. Genus Actinomyces, p. 1383-1418. In P. H. A. Sneath, N. S. Mair, M. E. Sharpe, and J. G. Holt (ed.), Bergey's manual of systematic bacteriology, vol. 2. The Williams \& Wilkins Co., Baltimore, Md.

10. Schaal, K. P. 1992. The genera Actinomyces, Arcanobacterium, and Rothia, $\mathrm{p}$ 850-905. In A. Balows, H. G. Trüper, M. Dworkin, W. Harder, and K. H Schleifer (ed.), The prokaryotes, vol. I. Springer-Verlag, New York, N.Y.

11. Schleifer, K. H., and O. Kandler. 1972. Peptidoglycan types of bacterial cell walls and their taxonomic implications. Bacteriol. Rev. 36:407-477.

12. Vandamme, P., M. Vancanneyt, B. Pot, L. Mels, B. Hoste, D. Dewettinck, L. Vlaes, C. Van Den Borre, R. Higgins, J. Hommez, K. Kersters, J.P. Butzler, and H. Goossens. 1992. Polyphasic taxonomic study of the emended genus Arcobacter with Arcobacter butzleri comb. nov. and Arcobacter skirrowii sp. nov., an aerotolerant bacterium isolated from veterinary sources. Int. J. Syst. Bacteriol. 42:344-356.

13. Wegienek, J., and C. A. Reddy. 1982. Taxonomic study of "Corynebacterium suis" Soltys and Spratling: proposal of Eubacterium suis (nom. rev.) comb. nov. Int. J. Syst. Bacteriol. 32:218-228.

14. Wüst, J., S. Stubbs, N. Weiss, G. Funke, and M. D. Collins. 1995. Assignment of Actinomyces pyogenes-like (CDC coryneform group E) bacteria to the genus Actinomyces as Actinomyces radingae sp. nov. and Actinomyces turicensis sp. nov. Lett. Appl. Microbiol. 20:76-81. 